University of Colombo Review (Series III),

Vol. 1, No. 1, 2020

\title{
The History of Smallpox Epidemics in Sri Lanka: Humanity's Triumph Over a Global Scourge
}

\author{
T. M. Zameer-Careem
}

MPhil candidate, Department of History, University of Colombo

ABSTRACT
For centuries, smallpox raged as a scourge, killing one third of those
who were infected, while those who survived were left blind, scarred
or disfigured for life. In the first half of the 20 th Century alone,
between 300 to 500 million people died of it, and even as late as the
1950s around 50 million people suffered from smallpox annually. The
smallpox epidemic which stalked Ceylon during Sri Sangabo's reign in
the Third Century wiped out half the country's populace. Many well-
known royals, aristocrats, military chiefs and clerics succumbed to
the disease. This article explores the history of smallpox epidemics,
variolation and vaccination in Ceylon. It also explores the sources of
the epidemic and measures taken by colonial governments to rein in
smallpox. It argues that smallpox was not endemic in Ceylon and that
it was always imported from overseas. It also argues that slavery and
indenture entailed the spread of epidemics and that variolation was not
introduced to Ceylon by the British. The last definitive case of smallpox
in the island was reported in 1967 and Ceylon became the first nation
in South Asia to eradicate smallpox. In May 1980, the World Health
Assembly declared that smallpox had been globally eradicated. This
"triumph over smallpox" was made possible because of global solidarity
and connectivity.
Smallpox epidemics, variolation, vaccination, British colonial era,
eradication

Suggested Citation: Zameer-Careem, T. M. (2020). The History of Smallpox Epidemics in Sri Lanka: Humanity's Triumph Over A Global Scourge. University of Colombo Review (Series III). 1 (1). 16 - 36

(C) 2020 The Authors. This work is licenced under a Creative Commons Attribution 4.0 International Licence which permits unrestricted use, distribution, and reproduction in any medium, provided the original work is properly cited.

\tuanzameerwrites@gmail.com 


\section{Introduction}

Smallpox was one of the most devastating scourges faced by humanity throughout recorded history. Caused by the variola virus, it is believed to have first appeared in agrarian settlements in North-Eastern Africa from where it spread to other regions through invasions and trade. Several Egyptian mummies excavated over the years have visible pox-scars, the most notable among them being that of Pharaoh Ramses V, who is said to have died of smallpox in 1157 BCE. The earliest recorded outbreak occurred in 1350 BCE during the Egyptian Hittite war (Hopkins, 2002). Smallpox was introduced to the Indian subcontinent by Egyptian traders somewhere in the first millennium BCE. In India, the disease was known locally as masurika, meaning lentil in Sanskrit, as lentils were poulticed onto the slow healing sores and because the pus-filled pox boils showed a great resemblance in shape, size and colour to masura, a local variety of lentils. The earliest written record of smallpox in India can be traced back to the Fourth Century CE., and the codex Madhava Nidana by Sri Madhavakara has a separate chapter, the 54th nidana (diagnosis), devoted wholly to masurika which had, by the early Eighth Century, evolved into a deadly epidemic that decimated large scale populations on the Indian subcontinent (Nicholas, 2003).

\section{The Pre-Colonial Era}

Throughout history, epidemics of smallpox have wiped out significant portions of the Lankan populace. Ayurvedic physicians of Ceylon had translated descriptions of smallpox from Sanskrit and Pali into Sinhala (Barnes, 2007; Cockburn, 1963). The Sinhala translation of Madhava Nidana was popular among the Ceylonese (Ainslie, 1829). Likewise, Bhesajja Manjusa (Casket of Medicine), a 13th Century medical treatise, which contains a section on smallpox (55th Chapter), was translated from Pali to Sinhala in the 18th Century by Valivita Saranankara Thero (Dharmananda, 1967). In Ceylon, smallpox was referred to by a multitude of terms such as vasuriya (derived from vasoori, Tamil for smallpox), vadura rogaya (disease inflicted by vadura demonesses), deviyange ledé (the divine affliction), maha leda (the great disease), divi dosey (leopard misfortune), raktawati (demon of infection), visphota, wasanta, rattakkha (Red-eyed demon) and masurika, derived from masura, Sanskrit for pulses (Clough, 1982; Deraniyagala, 1965; Fernando, 2005; Pridham, 1849; Senaveratne, 1920; Tennent, 1862 ; Wirz, 1954). It is surmised that smallpox (divi dosa) wreaked havoc in the time of Panduvasdeva who was himself afflicted by it but recovered. As smallpox was a highly contagious infection that spread rapidly, people had to abandon their villages and resettle elsewhere when epidemics broke out. Likewise, monarchs had to shift their seats of administration to other regions. Legend has it that epidemics of smallpox were among the major reasons that led to the collapse of the Rajarata Civilization (Intirapālā, 1971; Turner, 1923). According to Portuguese chronicler De Queyroz, Anurajapur (Anuradhapura) was abandoned because of war followed by smallpox, famine, and the plague (Pieris, 1992).

The earliest mention of a smallpox epidemic in the island is in the book, Eleven Years in Ceylon (1840) by Major Jonathan Forbes of the 78th Highlanders, who thought that smallpox had been known in Ceylon since the 3rd Century. Many historians and colonial 
authors note that variola came to Ceylon from India (Jennings, 1951). Nevill mentions in his note on the Vanni Puvata (Or. 6606[139]) that dignitaries of the Àriyavamsa clan from South India introduced smallpox to Ceylon during the Dambadeniya Period (De Silva, 1996).

Contrarily, George Fleming (1871), a Scottish veterinary surgeon who spent many years studying the diseases that afflicted Ceylonese and their livestock, surmises that smallpox was introduced to Ceylon from Africa in the 3rd Century. Although the exact place from where the infection was first imported to Ceylon remains obscure, it is highly probable that smallpox had been around since the 3rd Century. Legend also has it that a smallpox epidemic devastated Ceylon at the time of Arahat Mahinda Thero's sojourn. In the Taprobanian of June 1887, British civil servant Hugh L. Nevill records the belief that a giant Telambu tree (Sterculia foetida) which the natives believed to be an embodied form of the goddess Nava-Ratna-Valli/Ruvan-Vali had stood amid a sacred grove on the site of the Ruwanwaeli dagaba, and that when Arahat Mahinda Thero chose this site for the construction of the dagaba, the enraged goddess had "scattered pestilence around the country" (Pertold, 1933, p.10). Enormous sacrifices were made to pacify the goddess, and her tree was severed and the dagaba erected on the site.

According to Nevill, Nava-Ratna-Valli was an avatar of Pattini and Kali (Pertold, 1933, p.13). As they are both deities devoted to smallpox, it can be surmised that smallpox was the pestilence that stalked Ceylon at the time of Arahat Mahinda Thero's visit. Prince Sakka Sēnāpati, son of King Kassapa V (914-923 A.D.), who went to South India with a large force of Sinhalese soldiers to help Rajasinga Pandya battle against the Cholas, died of an epidemic termed upasagga/upasarga (Rasanayagam \& Rasanayagam, 1984; Warder, 2004). Throughout history, the Pandyan (Pandi) Kingdom had been ravaged by incessant epidemics of smallpox and according to Pantis-kol mura, the tutelary deity of Madura (the capital of Pandipura (Pandyan country)) is the small-pox goddess Waduru Ma Devi (Kanakasabhai, 1904; Nevill \& Deraniyagala, 1955; Sivaratnam, 1964). Moreover, smallpox (masurika) has been described under the title of upasarga (contact) in the 12th Century medical treatise, Harita Samhita (Girindranath, 1926; Rabb, 2019; Sharma, 1975). Hence, it is highly likely that Sakka Sēnāpati died of smallpox.

\section{The Portuguese Era}

The Portuguese conquistadors who sought out new worlds to explore and colonize brought with them not only their culture, language, and goods but also their deadly diseases. It is the Portuguese who introduced smallpox into Angola (Portuguese West Africa), the lower Congo Basin and Cape Town (Fenner, 1988; Hopkins, 2002). African slaves, whom the Portuguese brought to South America in droves, carried with them several infections including smallpox which, upon its introduction to Venezuela, Brazil, the Caribbean and other colonies, led to the depopulation of many native tribes. In 1562, within three months, 30,000 African slaves and native Indians perished in Brazil due to an epidemic of smallpox which was introduced to the colony by a Portuguese vessel that brought in slaves from Africa (Hays, 2005; Randall, 1977). It is estimated that $80 \%-95 \%$ of the native American 
population perished because of smallpox which was deliberately introduced to the New World by the European colonists (Mayor, 1995; Patterson \& Runge, 2002).

Unlike the American colonies, Ceylon had been exposed to incessant epidemics of smallpox long before the arrival of Europeans. Ian and Jenifer Glynn (2004) write, "Portuguese, Dutch and British in India and Ceylon, all found that smallpox had got there before them" (p. 37). Though attacks of smallpox were of very frequent occurrence, the disease was not endemic in Ceylon and was always invariably imported from India or other outside sources (Perry, 1902; United Nations, 1956). The report entitled Six-Year Programme of Investment issued by the Planning Secretariat states, however, that smallpox was endemic in Ceylon by the time the Portuguese arrived (1955, p. 378). Yet it is the case that the Portuguese and the Dutch introduced fresh waves of infection to Ceylon, mainly through the importation of mercenaries and slaves from Africa and India where smallpox was rife. In 1693 alone, the Dutch imported 47 slaves from Madagascar to Ceylon, and around 1660, the Dutch VOC transported more than 10,000 Indian slaves to Ceylon and Batavia (Allen, 2010; Schrikker \& Ekama, 2017). From 1694 to 1696, 3859 slaves from the Coromandel coast (India) were imported to Ceylon, and 510 slaves from Batavia arrived in Ceylon between 1761 and 1766 (Allen, 2015). S. N. Arseculeratne (2002) attributes the changes in the morbidity pattern during the colonial period to diet, habits and "to the importation of new diseases such as yaws, small-pox, venereal diseases and cholera, not only with the colonial personnel but also with hordes of immigrant labourers imported for the colonial enterprise" (p. 13). It should be noted that smallpox was one of the leading causes of death among the slaves dispatched from Ceylon (Ekama, 2012). Likewise, smallpox was often cited as the reason Cochin could not meet Ceylon's demand for slaves (Singh, 2010). Hence it is apparent that slavery and indenture entailed the spread of smallpox in Ceylon and other colonies.

Dom Luis and Dora João, the two Ceylonese princes of Kotte who were expected to ascend the thrones of Kotte and Jaffna respectively, died in the smallpox epidemic that raged through Goa in 1545 (Pieris, 1913). Dom Luis was the baptismal name of Jugo Bandara's brother and Dora João was the nephew of King Bhuvanekabāhu VII (his sister's son). They fled to India in 1545 with their respective entourages to seek help from the Viceroy of Goa, Dom João de Castro, to oust King Bhuvanekabāhu, who had planned to assassinate the two princes who were claimants to his throne. Shortly after their arrival in India, a captain to the King of Ceilam (Ceylon), his father, and a retinue of courtiers who had fallen out with Bhuvanekabāhu also arrived in Goa to support the two princes in their attempt to overthrow the king. Upon their arrival in Goa, they were baptized into the Catholic Church and together with the princes, lived at the quarters set up for the Ceylonese in the property of André de Sousa (Perera, 2004). In 1545, smallpox imported by the Portuguese broke out in epidemic form in Goa and 8,000 children alone succumbed within three months. Among those who perished in this epidemic were the two Ceylonese princes who died in the prime of their youth (Glynn \& Glynn, 2004; Pieris, 1913). The Portuguese Viceroy of Goa, D. João de Castro in his letter to the King of Kandy states, "On the 14th of January (1546) the princes of Ceylon died of small-pox in this city" (Perera, 2004, p. 7). Sir Paul E. Pieris 
(1920) mentions, however, that the Ceylonese princes died within a month of each other and that their bodies were interred with royal honours in the Convent of St. Francisco, Goa (p. 58). It is highly likely that several members of the princes' suite, attendants and slaves would also have died of smallpox although their names have gone unrecorded. In 1545 and 1548, when St. Francis Xavier \& his ambassadors visited Mannar, they nursed those labouring under the plague (Martyn, 2003). M. G. Francis (1913) surmises that smallpox could have been the plague that devastated Mannar at the time of St. Francis Xavier's visits. It should be noted that most colonial writers used the generic term "plague" to describe smallpox.

The first Ceylonese ruler to have died of smallpox in Ceilam (Ceylon) itself during the Portuguese era was Karalliyadde Banḍāra, alias Maastana (Pieris, 1920). In 1582, when Raja Sinha invaded the Kandyan Kingdom, Karalliyadde Banḍāra, his queen, family and entourage fled to Trincomalee accompanied by an escort of Portuguese soldiers. The royal family died there in a smallpox epidemic. King Karalliyadde's daughter, Kusumasana Devi (Dona Catherina), and his nephew and heir Yamasimha Bandara (Dom Philippe) were the only survivors in the family of the epidemic of 1582. In 1602, smallpox broke out in the camp of Samarakoon Rála, known among the Portuguese as Mudaliyár Dom Fernando Samarakon, and 700 of his Lascarin mercenaries as well as some valiant Arachchies, died of smallpox (De Queyroz, 1992; Pieris, 1914). The following March, another epidemic took the lives of the besieged defenders of the Talampitiya Fort (Hopkins, 2002).

During the Sinhalese-Portuguese revolt of 1618-19, native troops headed by Kuruvita Rala alias Antonio Barreto (Prince of Uva) set an ambush at the frontiers of the Sinhala Kingdom to snare the Portuguese army commanded by General Constantino de Sa de Noronha. When the Portuguese forces reached the frontiers, however, General de Sa received news of a smallpox epidemic which had broken out in Sabaragamuwa and that many Lascarins had died of it. Dismayed by the news General De Sa retreated to the lowlands, but while retreating he set an ambush for the native soldiers which proved successful (De Queyroz, 1992; De Silva, 1972). Later in 1621, immediately following this war, another epidemic of smallpox and fever broke out in the Fort of Jaffna to which many fell victim (De Silva, 1972). According to Pieris (1913) the villages in Jaffna were left desolate by the disease. In 1648, hundreds of Bharatha fishers on the isle of Mannar died of smallpox. The Jesuit priest, Balthasar da Costa, in his letter to Vincenzo Carafa, dated 28 November 1648 writes that, "The greater part of them died in a few days of small-pox, which is a plague in this country" (Perera, 1919, p. 86). He goes on to give a chilling account of a smallpox victim, a slave who was rescued by a Christian priest from being buried alive. In 1656, when Colombo was besieged by Dutch troops, many Portuguese soldiers who were trapped in the Colombo fort died of smallpox, plague and starvation. In fact, smallpox epidemics disrupted many of the wars fought during the Portuguese colonial period (da Silva Cosme, 1990). 


\section{The Dutch Era}

During the Dutch colonial period, Ceylon was ravaged by smallpox which prevailed usually in the months of October, November and December during the North-East monsoon. Whenever an epidemic struck the island, it scarcely ever failed to visit Colombo (Kinnis, 1835). For instance, a major epidemic broke out in the Kandyan province in the middle of 1697 and spread furiously throughout the island, including the Dutch-controlled territories. King Vimaladharmasooriya fled the capital and sought refuge in the mountains, abandoning those seized with smallpox to die in their homes, or disposing of their bodies in the forests to be devoured by animals, instead of taking them to the hospitals. It was during the epidemic of 1697 that Fr. Joseph Vaz and his nephew, Fr. Carvalho, sought out those abandoned in the forests and nursed them in make-shift huts (Chitty, 1848). Later in the years $1747 \&$ 1748, smallpox epidemics and pestilent fever (probably malaria) raged through the entire South-West lowlands, between Kalpitiya and the river Walave (De Silva, 2005). According to the writings of Governor Van Gollonesse, the smallpox epidemics that devastated Ceylon in the 1740s also had a devastating impact on the production of areca nut which was among the many commodities exported to South India during the Dutch Colonial period (Dewasiri, 2008).

In 1754, a smallpox epidemic which broke out in the Maritime Provinces took a great toll on the population and lasted for more than a year. According to Governor Loten, this epidemic of 1754-55 not only claimed many victims but also caused severe social disruption in Ceylon (Reimers, 1935). Governor Loten (1752-57) in his Memorandum of Instructions handed over to his successor Jan Schreuder on 28 February 1757, states that in Ceylon, even the nearest blood-relations left those seized with smallpox to perish without help or medicine. He also deplored the ineffective treatment procedures employed by the Ceylonese (Raat, 2010). He was incensed at the unwillingness of the natives to get themselves inoculated which was the only viable remedy at the time.

Smallpox exerted an important influence on the course of military campaigns during the Dutch period as well. During the Dutch-Kandyan War of 1762-65, a great majority of soldiers of the Dutch regiments, mainly native auxiliaries, Indian Sepoys and Malay mercenaries perished due to outbreaks of the disease (De Silva, 1959). Raven-Hart (1964) writes, "All is well, except that smallpox is raging among the Sipahis, Kaleros, Kamadjes and Singalese, of whom we have fully 1500 in the force" (p. 108). Dr. J. R. Blaze (1960), in his article entitled "The Campaign of 1764" notes that many coolies in the Dutch camp fell sick and eventually died of a smallpox epidemic during the campaign of 1764, the last great war of the Dutch in Ceylon. According to Major Pierre Duflo, the Dutch lost many mercenaries and coolies to smallpox, which the "Singalese feared as the plague" (RavenHart, 1964, p. 158). The Dutch expedition of 1765 was also marred by smallpox which raged fearfully among the mercenaries and coolies (Cordiner, 1807).

\section{The British Era}

During the British colonial era, Ceylon was ravaged by incessant episodes of smallpox brought in by traders, fishers, indentured labourers (coolies) and Sepoy mercenaries from 
India, or introduced by ships from Chinese and other Eastern ports (Report on Public Health, 1918). The first major outbreak under British rule occurred in the Pettah (Black Town) of Trincomalee in 1799, where it wreaked great devastation among the natives and the Europeans (Christie, 1811). It soon spread to other regions of the island, including Colombo. In February 1799 when the King of Kandy dispatched his chief Adigar (Minister) to meet Governor North, they met at Avisahavile (Avissawella) instead of Colombo, because the King's emissary declined visiting the capital which was then affected by a smallpox epidemic (Marshall, 1846).

The second outbreak in 1800 swept through Trincomalee, Batticaloa, Tamankaduwa and the South-West of the island, killing thousands and causing much misery to the inhabitants of the region (Levers, 1899). Dr. Christie, in his letter to Sir Walter Farquhar, 1st Baronet, dated 19 November 1802, laid out the unimaginable horrors he witnessed in the village of Errore, in Batticaloa, on the Eastern coast of Ceylon, which had been devastated because of a smallpox epidemic that had broken out in July 1800. When Dr. Christie visited the village in September that year, he found that all its inhabitants had deserted their homes, leaving to their fate their unfortunate relatives and friends who had fallen ill. The village of Undewally (identified as Vandermal by Cordiner) was also heavily ravaged by the epidemic of 1800, and when Dr. Christie, accompanied by Rev. Cordiner, visited Undewally on 4 September 1802, they found 40 people who had died of smallpox and 10 who had recovered. Dr. Christie (1811), in his report on vaccination states that according to moderate estimates, smallpox had carried off "a sixth part of the population; yet no attempt was made by the Dutch Government to lessen this destruction" (Moore, 1815, p. 238; see also Guy, 1851).

\section{Protection against Smallpox}

Prior to the discovery of the smallpox vaccine by British doctor Edward Jenner in 1796, variolous inoculation, the lethal procedure of infecting people with low doses of smallpox, was the only form of protection against the disease. In the Memorandum of Instruction he wrote for his successor Jan Schreuder, Governor J. G. Loten commented on variolous inoculation in Ceylon (Uragoda, 1987). Following a major outbreak in 1786, Governor Van de Graffe had initiated a campaign under the supervision of the chief surgeon of Galle, Major Frans Wolkers, to inoculate the people of Ceylon against smallpox (Schrikker, 2007). Major Wolkers who couldn't supervize the campaign alone, requested the Governor to appoint a junior surgeon to assist him in his efforts (Uragoda, 1987). In January 1791, another inoculation campaign was carried out under the orders of Van de Graaffe.

In fact, it was the Dutch who taught the Bantu in Africa and the Javanese the practice of variolation (Spinage, 2012; Theal, 1919; Van Doornum et al., 2020). Likewise, it was a Dutch physician, A. L. Bernard Keller, who introduced the surgical, Turkish-style variolation to Japan at the end of the 18th Century (Furukawa, 1994). Therefore, it is most likely that variolation was introduced to Ceylon by the Dutch. According to White (1885), when the British seized Ceylon from the Dutch in 1795, most areas of the island had been affected. 
Unlike their predecessors, the British took active measures to rein in smallpox. Margaret Carnie, an Englishwoman belonging to His Majesty's 80th regiment, who was about to deliver a baby died of confluent smallpox on the 17 November 1799 in Trincomalee. Her infant, born in apparent good health on the 12 November, died of convulsions a few days later. Following this tragic incident, 17 men, a proportion of European children, natives attached to HM's 80th regiment and a few gun lascars were inoculated against smallpox (Christie, 1811).

Between 1799 and early 1800, the number inoculated did not exceed 50 or 60, yet, as all these cases were successful, it paved the way for its more general adoption and for the establishment of smallpox hospitals (Christie, 1811). Governor Frederick North, who was well informed of the ravages of smallpox epidemics in the island, established the first hospital in Trincomalee in early 1800, and appointed Dr. Christie as its superintendent (Christie, 1811). Smallpox hospitals were also erected in other principal districts under British possession, viz. Colombo, Jaffna, and Galle. These establishments started functioning from April 1800, and each district was supervized by an English surgeon under whose jurisdiction a European medical officer was placed in charge of the hospital. Each hospital also had a reputed Burgher as purveyor who managed the economy of the establishment (Christie, 1811). Governor North also appointed European medical overseers and medical assistants to the districts of Colombo, Kalutara, Galle, Matara, Batticoloa, Trincomalee, Mullaitivu, Jaffna, Mannar, Puttalam, Chilaw, and Negombo.

As part of his successful fight against small-pox, Governor North also appointed medical attendants to nurse the sick in the villages. On 7 September 1800, a proclamation was issued by North, requesting government officials to send medical supplies to threatened villages (Legislative Acts 1796-1833, 1852). If someone in the village fell victim to smallpox, the Vidaane (village police officer) was required to report the case to the Mudaliyar, who in turn would report it to the Magistrate of the district, who would then send a medical overseer or an assistant to the respective village where the disease prevailed. This was to prevent the spread of infection and to perform inoculation with the approval of the superintendent. From 1 October 1800 to 30 September 1802, 2110 persons were provided treatment and 4158 persons were inoculated against smallpox by medical overseers in different hospitals and villages. Despite these efforts, one fourth of the patients who were infected, and one in thirty-eight of those inoculated died of smallpox (Christie, 1811).

Thomas Christie, who had heard of the virtues of vaccination, attempted all means of importing the vaccine to Ceylon from Europe (Moore, 1815). As those infected with cowpox, which is similar to, but much milder than smallpox, conferred specific immunity to smallpox, Dr. Christie searched for cowpox among the cows of Ceylon, but to no avail (p. 239). Dr. Jenner sent to Ceylon coloured drawings of the vaccine vesicle in all stages and is reported to have also sent out packets of dried lymph on numerous occasions ( $p$. 239). The smallpox vaccine (Jenner's original vaccination used lymph from pustules of infected cows) dispatched from Vienna reached Bombay in May 1802, and on 14 June 1802, Dr. Helenus Scott made a successful inoculation on the arm of a three-year-old 
Anglo-Indian child, Anna Dusthall, in Bombay (Bhattacharya, 2014). On 10 July 1802, Dr. Scott sent to Ceylon a packet containing, "some threads well soaked in vaccine lymph, and enclosed in silver tubes, stopped with wax" which reached Trincomalee on 11 August, and a surgeon immediately vaccinated six children with these threads (Moore, 1815). According to Dr. Christie's letter to Sir Walter Farquhar, dated 19 November 1802, the first successful vaccination in Ceylon was performed on a Burgher named John Sybelle on 11August and as soon as success was ascertained in this instance, other patients were vaccinated with lymph derived from John Sybelle starting from 20 August.

In the 1800s, "arm-to-arm passage" (transmission of lymph taken from a vesicle or pustule of a previously vaccinated person to another) was the primary method of human vaccination and underprivileged children were used as live carriers of the vaccine. It is said that parents were bribed by the medical authorities to allow their children to be vaccinated and that mothers were paid to accompany their children (Bennett, 2020). From Ceylon, the first active virus was carried by the ship "Hunter" to Madras, from where it was sent to Calcutta, and thereafter throughout India (Christie, 1805). Following the advent of vaccination, the British banned variolation in Ceylon in 1802 (Christie, 1811; Kinnis, 1839; Kirkpatrick, 1910; Moore, 1815; White, 1885). This made Ceylon the first country in the world where variolation was prohibited. In fact, it was not until 1840 that variolation was prohibited by law even in England and Ireland (Gregory, 1846; Rickards, 1893; Stallybrass, 1931). In British India, although it was outlawed in 1870, variolation remained in practice, particularly in the princely states, up until the mid-20th Century (Basu, et al., 1979; Bhattacharya, 2014; Fenner, et al., 1988). It also continued to be practiced into the 1960s and 70s among remote populations in parts of Afghanistan, Ethiopia, Pakistan, China, Western and Sub-Saharan Africa (Fenner, et al., 1988; Imperato \& Imperato, 2014).

Elsewhere, the success of the smallpox vaccine spread, and natives flocked to hospitals to get themselves vaccinated. The medical superintendents and overseers previously employed to perform variolous inoculation were transferred to vaccine departments where vaccination was practiced every morning by the European surgeons (Christie, 1811; Kinnis, 1838). The medical overseers were also ordered to travel to every village in their respective districts to vaccinate as many as they could. In order to further induce the natives, officials distributed pamphlets and made public addresses to raise awareness about the efficacy of the vaccine against smallpox. An experiment to evaluate the vaccine's safety and effectiveness was also performed in Jaffna on the request of a Dutch officer, Lieutenant Theil, who submitted his two children who had earlier been vaccinated with cowpox to be inoculated by Dr. John Carnie with the smallpox virus. "An address to the natives of Ceylon" published by the British government in September 1802 also explained the benefits of the vaccine in Dutch, Malabar (Tamil), Sinhalese and English, and urged the Ceylonese to avail themselves of the benefits of vaccination (Bennett, 2020; Christie, 1811).

The arm-to-arm passage which was the primary method of human vaccination in the 1800 s was not a safe practice as sometimes the vaccine became contaminated with other viruses and this led to the outbreak of other infections. In March 1804, the inhabitants of Jaffna expressed opposition to vaccination because of an error caused by Sinhalese 
practitioners who had mistakenly vaccinated the people of Jaffna with contaminated matter. This led to many dying of smallpox which had broken out earlier that year (Kinnis, 1838). In order to placate the situation and prevent the inhabitants of Jaffna from reverting to the practice of variolous inoculation, Dr. Christie travelled to Jaffna, remained there for almost a month and introduced the genuine vaccine from Trincomalee convincing the locals to get vaccinated (Kinnis, 1838). Thereafter, vaccination against smallpox was routinely performed in Jaffna albeit not without considerable opposition from the locals who had formerly survived by submitting to variolous inoculation (Moore, 1815). In the southern part of the country, the Chief Mudaliar of Matara, submitted his infant child for vaccination while the headman at Dondra induced his people to be vaccinated (Bennett, 2020; Christie, 1811). By April 1804, 20,000 individuals had been vaccinated and smallpox was declared eradicated in Galle, Matara, Hambanthota and Colombo (Kinnis, 1838).

The natives of the Kandyan provinces, however, were unprotected against smallpox as rumour was that vaccination meant taking an oath in favour of British rule and many were of the opinion that the smallpox vaccination was pointless and reaped no benefit (Hopkins, 2002; Marglin, 1987). Smallpox depopulated several villages in the Kandyan provinces and it left surviving populations gravely weakened and much less able to resist European encroachment than they would have otherwise been. Although vaccination was introduced to Ceylon in 1802, it was made available in the Kandyan provinces only in September 1816, following the signing of the Kandyan Convention and accession of Kandy to British Ceylon (Kinnis, 1838). The British authorities, having realized the prominence of hierarchies in social relations and its influence on the natives of Kandy, persuaded the Nilames, headmen and clergy to undergo vaccination, assuming that the natives would follow suit. However, it was not easy to induce them to submit to vaccination. Keppetipola Disawe was the only Kandyan chieftain to have allowed British medical officers to vaccinate him and his family (Marshall, 1823).

Keppetipola's family survived the epidemic of 1819 which decimated many other prominent families. Lawrie notes that "In 1819 hardly a member of the leading families, the heads of the people, remained alive; those whom the sword and the gun had spared, cholera and smallpox and privations had slain by hundreds" (Coomaraswamy, 1908, p. 15). Galagoda Disawe of Nuwarakalawiya and Walapane Disawe were among the long list of native chiefs who were seized with smallpox, although the latter survived (Lawrie, 1898). It is said that when Ellepola Ihagama Kumarihamy, the widow of Ellepola Maha Nilame Adigar of Matale, contracted the infection, the people in her house who had pillaged her of her riches flung her out like offal onto the streets (Madugalle, 2005). According to Sir Archibald Lawrie (1896), childless Ellepola Kumarihamy died a pauper on 16 October 1819 and a constable found her naked corpse covered with blood and pox boils. The government spent eight Rix dollars to bury her as the body was not claimed by any of her relations.

Following the catastrophic 1819-20 epidemic, even the most orthodox Kandyan gentry, political dissidents and members of the Hindu and Buddhist clergy submitted themselves to vaccination, thus promoting the practice of immunization against smallpox among the natives of Ceylon. Some of them ably assisted the British in their attempt to 
promote immunization. In 1820, regulations were passed by the government making notification of small pox cases obligatory in order to prevent its spread within settlements (Legislative Acts 1796-1833, 1852, pp. 246-258). Another regulation enacted in 1820 forbade persons from landing from a ship till the port authorities were convinced that there were no cases of smallpox or other contagious infections on board (Uragoda, 1987). In 1837, a complete system of compulsory domestic quarantine was established in Ceylon although it received considerable opposition from the inhabitants of Colombo and Jaffna (Gregory, 1852).

On the 10 July 1832, a special meeting took place at the Audience Hall of Kandy, where Governor Sir Wilmot Horton addressed the natives on the subject of vaccination and in response, Buddhist monks pledged their support to the Governor. Printed copies of the Governor's speech were circulated throughout the Kandyan provinces to raise awareness on the benefits of vaccination (Holman, 1834). The British also induced several native doctors to learn the procedure of cowpox inoculation, and this led to the abandonment of the perilous variolation procedure. A great majority of the natives, particularly those who belonged to the seven Korales of the Kandyan provinces, did not wholly understand vaccination which was known among locals as ath irima (tearing of hand) or as ath paleema (the dividing of the arm) which occurred when inducing them to submit to vaccination. Some Buddhist monks, kapuwa/kapurale and kattadias also vehemently opposed vaccination and forbade their followers from going to the vaccinators (Holman, 1840). According to the Report of the Small-pox Quarantine Committee (1852), when Mahalpe Unanse, a Buddhist monk, was questioned about the efficacy of vaccination, he not only stated that he does not have sufficient faith in it but also declared, "I was never vaccinated....a Buddhist would do wrong in performing the act of vaccination" (p. 148).

The Hindu priests of Ceylon, particularly those belonging to the Brahmin caste, expressed less disapproval of vaccination as compared to the Buddhist and Muslim clergy. In the last two months of 1809 , around 1830 persons were vaccinated in the district of Jaffna, among whom were several Brahmins who had up to then declined vaccination (Kinnis, 1835). It was believed that, as the Hindus hold cows in great veneration, they eagerly submitted to vaccination after being informed that the substance introduced after the skin was punctured was extracted from cows and that it prevented the disease (Thomson, 1809). According to Dr. Bateman's account on the progress of vaccination, Brahmins not only submitted to this effectual safeguard from smallpox surmounting their religious prejudices but also expressed gratitude for such a blessing (1811, p. 393). Similarly, H. Dickman who was the Medical sub Assistant in charge of the smallpox hospital in Pettah wrote that "Brahmins of Colombo voluntarily came forward to be vaccinated" (1852, p. 38). In 1863, Ceylon became the first British colony in Asia where vaccination was made compulsory by an Ordinance (Ceylon, 1864; Colonial Office, 1866; Vanderstraaten, 1886)

According to the Vaccination Inquirer and Health Review (1882), Ceylon was among the few British colonies where vaccination was thought to be extremely successful, and Sir Edward Jenner used Ceylon as one of the prime examples of the efficacy of his discovery (Baron, 1827; Gregory, 1852). In a letter to William Dillwyn of Walthamstow in 1818, 
Jenner wrote "In the land of Ceylon, the ravages of small-pox were dreadful. But after a little time the people took to vaccine inoculation very readily, and small-pox became totally extinct" (White, 1885, p. 345). In the words of Dr. George Gregory, writing in 1843, "So successful were their labours (of vaccination), that, up to the beginning of 1819, it had often been said that the experiment exterminating smallpox, had been made and successfully carried out in Ceylon" (Gibbs, 1856, p. 11; Gregory, 1843, p. 210). Dr. Jenner, who highly valued the medical progress made in Ceylon, urged Dr. Christie to publish an account of the introduction, progress, and success of vaccination in Ceylon, believing that it might help eradicate smallpox elsewhere (Baron, 1827; White, 1885). Between the years 1802 and 1807, under the direction of Dr. Christie, 76, 828 persons were regularly vaccinated (Christie, 1811). The consequence was that no cases of smallpox were reported throughout the island from February 1808 to October 1809 (Baron, 1827; Christie, 1811; White, 1885).

This made Ceylon the first non-European country where such a feat was achieved. Ogden (1987) suspects that Ceylon was the first country in the world to eliminate smallpox in the early 1800 s. As early as the 1820 s, Ceylon had also become one of the first countries to issue vaccination certificates against smallpox. To limit the further introduction of communicable diseases from mainland India through both rail and sea-routes, the British established quarantine camps at Mandapam, Ramnad district and in Tataparai in Tuticorin (Ceylon Year Book, 1955; United Nations, 1956). The islets of Mandaitivu and Velanai, off the coast of Jaffna Peninsula had been depleted by the smallpox epidemic which struck Ceylon in 1884. Mandaitivu was later used as a quarantine zone where those affected by the epidemics of the late 19th Century were housed (Bassett, 1929). There was also a quarantine station in Hammenheil, near Kayts. In 1897, the Quarantine and Prevention of Diseases Ordinance No. 3 was enacted, and quarantine camps were established at Ragama and Tataparai the same year (Gnanamuttu, 1977; World Health Organization, 1961). The colonial government introduced a series of laws and regulations relating to quarantine to prevent the entry of infected persons from India and elsewhere. Regulations were also imposed on Roman Catholic priests and pilgrims visiting Ceylon (Bastiampillai, 2006; Sivasundaram, 2013). Fumigation was also used as a preventive measure. According to the Administrative Report of 1926, smallpox was brought by the vessels S.S. Katuna, S.S. Karroo and S.S. Clan McNair and on arrival, the vessels were fumigated and all cases and their contacts were removed to the Infectious Diseases Hospital while the officers and crew were vaccinated (1928).

\section{Conclusion}

On 22 December 1967, Sri Lanka's last known smallpox patient, a 47-year-old sportsman who had returned from a tour to Madras, India, was admitted to a private hospital after he presented symptoms pointing strongly towards smallpox. He was immediately isolated at the Infectious Diseases Hospital (IDH) Angoda, and the case was virologically confirmed as smallpox on 26 December 1967 (Gunasekara, 1973). On 8 May 1980, the 33rd World Health Assembly declared that smallpox was globally eradicated. From the many examples presented above, it is clear that smallpox was not endemic to Ceylon 
but imported from abroad, particularly by those who travelled to, and from, India. It is global connectivity that led to the importation of deadly diseases like smallpox to Ceylon. Likewise, vessels from Ceylon carried the disease to foreign lands. Smallpox that ravaged the Dutch Cape Colony in 1755 arrived on a vessel from Ceylon and again in 1767, a Danish vessel homeward bound from Ceylon instigated the third major smallpox epidemic in South Africa (Jackson, 1869; Laidler \& Gelfand, 1971; Murray, 1835). Ceylon, however, also benefited enormously from global connectivity. The native remedies for pox boils and its associated complications were heavily borrowed from Indian medical codices. Variolation which was introduced from abroad generated immunity in many cases, and the advent of a smallpox vaccine in August 1802 brought about a complete change in its eradication campaign. Smallpox was, therefore, both spread and arrested through global connectivity.

\section{References}

Ainslie, W. (1829). Observations respecting the small-pox and inoculation in Eastern countries with some account of the introduction of vaccination into India. Transactions of the Royal Asiatic Society of Great Britain and Ireland, 2(1), 52-73. Retrieved October 18, 2020, from http:// www.jstor.org/stable/25563420

Allen, R. B. (2010). Satisfying the "want for labouring people": European slave trading in the Indian Ocean, 1500-1850. Journal of World History, 21(1), 45-73. Retrieved October 18, 2020, from http://www.jstor.org/stable/20752925

Allen, R. B. (2015). European slave trading in the Indian Ocean, 1500-1850. Ohio University Press. Arseculeratne, S. N. (2002). Interactions between traditional medicine and 'Western' medicine in Sri Lanka. Social Scientist, 30(5/6), 4-17. doi:10.2307/3517999

Barnes, E. (2007). Diseases and human evolution. UNM Press.

Baron, J. (1827). The Life of Edward Jenner MD with illustrations of his doctrines and selections from his correspondence (Vol. 1). Henry Colburn.

Bassett, R. H., Laws, E. J., \& Murdoch, K. (1929). Romantic Ceylon. Palmer.

Bastiampillai, B. (2006). Northern Ceylon (Sri Lanka) in the 19th Century. Godage International Publishers.

Basu, R. N., Jezek, Z., \& Ward, N. A. (1979). The eradication of smallpox from India. World Health Organization South East Asia Regional Office.

Bateman, T. (1811). On the progress and present state of the practice of vaccination. The Medical and Physical Journal, 26. https://www.ncbi.nlm.nih.gov/pmc/articles/PMC5699355/

Bennett, M. (2020). The war against smallpox: Edward Jenner and the global spread of vaccination. Cambridge University Press.

Bhattacharya, S. (2014). Unseen enemy: The English, disease, and medicine in colonial Bengal, 1617 - 1847. Cambridge Scholars Publishing.

Blaze, J. R. (1960). The campaign of 1764. Journal of the Dutch Burgher Union of Ceylon 50 (12), 36-48. https://thedutchburgherunion.org/journals/vol_41_50/JDBU\%20Vol\%2050\%20 No\%201-2\%20-\%201960\%281\%29.pdf

Ceylon Administrative Report for 1926. (1928). Ceylon Government Press.

Ceylon Year Book (1955). Department of Census and Statistics. 
Chitty, S. C. (1848). The Life of Father Joseph Vaz: founder of the Catholic Mission of the Oratory of Saint Philip Neri in Ceylon.

Christie T. (1805). Mr. Christie, on Vaccination. The Medical and physical journal, 13(72), 122-128. https://www.ncbi.nlm.nih.gov/pmc/articles/PMC5670390/?page=1

Christie, T. (1811). An account of the ravages committed in Ceylon by small-pox previous to the introduction of vaccination; with a statement of the circumstances attending the introduction, progress and success of vaccine inoculation in that island. J. \& S. Griffith.

Clough, B. (1982). Clough's Sinhala English dictionary (2nd Ed.). Asian Educational Services.

Cockburn, A. (1963). The Evolution and Eradication of Infectious Diseases. Baltimore: Johns Hopkins University Press.

A collection of legislative acts of the Ceylon Government from 1796 to 1833: Distinguishing those now in force (Vol. 1, 1796/1833). (1852).W. Skeen, Government Printers.

Colonial Office. (1866). Reports showing the present state of Her Majesty's colonial possessions, transmitted with the Blue Books for the year 1864 (Part II, North American colonies, African settlements and St. Helena, Australian colonies and New Zealand, Eastern colonies, and the Mediterranean possessions, \& C). H. M. Stationery Office.

Coomaraswamy, A. K. (1908). Mediceval Sinhalese art. Essex House Press.

Cordiner, J. (1807). A description of Ceylon, containing an account of the country, inhabitants, and natural productions: with narratives of a tour round the island in 1800, the campaign in Candy in 1803, and a journey to Ramisseram in 1804 (Vol. 1). Longman, Hurst, Rees, and Orme.

da Silva Cosme, O. M. (1990). Fidalgos in the Kingdom of Kotte, Sri Lanka, 1505-1656: The Portuguese in Sri Lanka. Harwoods publishers.

De Queyroz, F. (1992). The temporal and spiritual conquest of. Ceylon, S. G. Perera (Trans.). Ceylon Government Printers.

Deraniyagala, P. E. P. (1965). Some grooves that were probably produced by polishing stone cells. Spolia Zeylanica, 30(2). 261-63.

De Silva, C. R. (1972). The Portuguese in Ceylon, 1617-1638. H. W. Cave.

De Silva, D. G. B. (1996). Hugh Nevill memorial lecture - II: New light on vanniyās and their chieftaincies based on folk historical tradition as found in palm-leaf mss. Journal of the Royal Asiatic Society of Sri Lanka, 41, 153-204.

De Silva, K. M. (1959). History of Ceylon, vol. 3. Colombo: University of Ceylon.

De Silva, K. M. (2005). A history of Sri Lanka. Vijitha Yapa Publications.

De Silva, W., Gooneratne, E., \& Attygalle, J. (1913). The medical literature of the Sinhalese. The Journal of the Ceylon Branch of the Royal Asiatic Society of Great Britain \& Ireland, 23(66), 34-50. Retrieved October 18, 2020, from http://www.jstor.org/stable/43483084

Dewasiri, N. R. (2008). The Adaptable Peasant: Agrarian Society in Western Sri Lanka Under Dutch Rule, 1740-1800. Brill.

Dickman, H. (1852). Report of the Small-pox Quarantine Committee: Appointed by order of His Excellency the Governor. W. Skeen, Government printer.

Dharmananda, V. D. S. (1967). Bhesajjamaňjusa nutana sannaya. Kimsila Press.

Ekama, K. (2012). Slavery in Dutch Colombo. A Social History. Masters Research Thesis, (Leiden 2012). Engerman, Stanley, Servants to slaves to servants: contract labour and European expansion'in PC Emmer (ed.), Colonialism and Migration. 
Fenner, F., Henderson, D. A., Arita, I., Jezek, Z., \& Ladnyi, I. D. (1988). Early efforts at control: variolation, vaccination, and isolation and quarantine. History of International Public Health, 6, 245-276. World Health Organization.

Fernando, M.S. (2005). Rituals, folk beliefs and magical arts of Sri Lanka. Susan International. Fleming, G. (1871). Animal plagues: their history, nature, and prevention. Chapman \& Hall.

Forbes, J. \& Turnour, G. (1840). Eleven years in Ceylon: Comprising sketches of the field sports and natural history of that colony, and an account of its history and antiquities: Vol. 1. Richard Bentley.

Furukawa, A. (1994). Medical history through postage stamps. Medico Dental Media Intl Inc.

Gibbs, J. (1856). More words on Vaccination: Being appendices to his letter on compulsory vaccination to the board of health. Willis and Sotheran.

Girindranath, M. B. (1926). History of Indian medicine: containing notices, biographical and bibliographical, of the ayurvedic physicians and their works on medicine. University of Calcutta.

Glynn, I. \& Glynn J. (2004). The life and death of smallpox. Profile Books.

Gnanamuttu, G. A. (1977). Education and the Indian plantation worker in Sri Lanka. Gnanamuttu.

Government of Ceylon. (1864). The Acts of Ceylon. Government Printer

Gregory, G. (1843). Lectures on the eruptive fevers; Delivered at St. Thomas's hospital, in January, 1843. Henry Renshaw, 356, Strand.

Gregory, G. (1846). Elements of the theory and practice of Medicine. London: Henry Renshaw and Strand.

Gregory, G. (1852). Smallpox in Ceylon, compulsory-vaccination. The Medical Times and Gazette, A Journal of Medical Science, Literature, criticism and news, New Series 5.

Gunasekara, D. B. (1973). Administrative Report of the Director of Health Services for the year 1967-68. Department of Health Services.

Guy, W. A. (1851). Lectures on public health. The Medical Times: A journal of Medical Science 2. John Churchill.

Hays, J. N. (2005). Epidemics and pandemics: Their impacts on human history. ABC-Clio.

Holman, J. (1834). A voyage round the world from 1827 to 1832. Smith, Elder, and Co.

Holman, J. (1840). Travels in Madras, Ceylon, Mauritius, Cormoro Islands, Zanzibar, Calcutta, Etc., Etc (Vol. 3). G. Routledge.

Hopkins, D. R. (2002). The greatest killer: smallpox in history (Vol. 793). University of Chicago Press.

Imperato, P. J., \& Imperato, G. H. (2014). Smallpox Inoculation (Variolation) in East Africa with Special Reference to the Practice among the Boran and Gabra of Northern Kenya. Journal of Community Health, 39, 1053-1062.

Intirapālā, K. (Ed.). (1971). The Collapse of the Rajarata Civilization in Ceylon and the Drift to the South-West: a symposium. Ceylon Studies Seminar. University of Ceylon.

Jackson, J. D. (1869). A case of Varicella with some commentaries on the identity of varicella and variola. Richmond and Louisville Medical Journal, 7. p.20.

Jennings, I. (1951). The economy of Ceylon. Oxford University Press.

Kanakasabhai, V. (1904). The Tamils eighteen hundred years ago. Higginbotham. 
Kinnis, J. (1835). A report on small-pox as it appeared in Ceylon in 1833-34, with an appendix. Government Press.

Kinnis, J. (1838). Smallpox and vaccination in Ceylon. The Boston Medical and Surgical Journal, 19(2), 21-25, 69-72.

Kinnis, J. (1839). On the Advantages of Vaccination. The British And Foreign Medical Review or Quarterly Journal of Practical Medicine and Surgery Volume 7. John Churchill.

Kirkpatrick, T. P. C. (1910). History of the prevention of smallpox. Transactions of the Royal Academy of Medicine in Ireland: Vol. I-XXXVI and XXXVII... (Vol. 9). J. Falconer. 426-482

Laidler, P. W. \& Gelfand, M. (1971). South Africa: its medical history 1652 - 1898: A medical and social study. Struik.

Lawrie, A. C. 1896). A gazetteer of the Central Province of Ceylon (excluding Walapane). (Vol. 1) G. J. A. Skeen.

Lawrie, A. (1898). A gazetteer of the Central Province of Ceylon (excluding Walapanne). (Vol. 2). G.J.A. Skeen.

Levers, R. W. (1899). Manual of the North-Central Province, Ceylon. G. J. A. Skeen.

Madugalle, Sunil J. (2005). Four Kandyan families from the Maha Disawani of Matale, Uva and Dumbara Pasrata: A genealogical study within the historical background and the geographical spread of the Kandyan Kingdom (1600-1815) 1600-2000. Vijitha Yapa Publications

Marglin, F. A. (1987). Smallpox in two systems of knowledge. Prepared for the UNU/WIDER planning meeting on systems of knowledge as systems of domination 21-23 July 1987 (Working Paper No. 17). UNU/WIDER.

Marshall, H. (1823). Some Account of the Introduction of Vaccination among the Inhabitants of the Interior of Ceylon, and of an Epidemic Small-Pox Which Prevailed in the Kandyan Provinces in 1819. Edinburgh Medical and Surgical Journal, 19(74), 71.

Marshall, H. (1846). Ceylon: A General Description of the Island and Its Inhabitants, with an Historical Sketch of the Conquest of the Colony by the English (No. 1-6). WH Allen.

Martyn, J. H. (2003). Martyn's notes on Jaffna: Chronological, historical, biographical. Asian Educational Services.

Mayor, A. (1995). The Nessus Shirt in the New World: Smallpox Blankets in History and Legend. The Journal of American Folklore, 108(427), 54-77. doi:10.2307/541734

Moore, J. C. (1815). The history of the small pox. Longman, Hurst, Rees, Orme \& Brown.

Murray, J. (1835). On Variola and varicella. London Medical Gazette, 15. Longman.

National Anti-Vaccination League (1882). London Society for the Abolition of Compulsory Vaccination. The Vaccination inquirer and health review. London.

Nevill, H. \& Deraniyagala, P. E. P. (Ed.) (1955). Sinhala verse-Kavi. Ethnology, Collected by the late Hugh Nevill (1869-1886). Ceylon Government Press.

Nicholas, R. W. (2003). Fruits of worship: practical religion in Bengal. Orient Blackswan.

Ogden, H. G. (1987). CDC and the Smallpox Crusade (No. 8400). US Department of Health and Human Services, Public Health Service, Centers for Disease Control.

Patterson, K. B., \& Runge, T. (2002). Smallpox and the Native American. The American Journal of the Medical Sciences, 323(4), 216-222. https://doi.org/10.1097/00000441-200204000-00009 
Perera, S. G. (1919). The Jesuits in Ceylon (in the XVI and XVII centuries). Ceylon Antiquary and Literary Register. 81-87.

Perera, S. G. (2004). Jesuits in Ceylon (in the XVI and XVII Centuries). Asian Educational Services. Perry, A. (1902). Ceylon Government Sessional Papers (Vol. 66.). H. M. Stationery Office

Pertold, O. (1933). The legend of the Princes Ratanavali as a problem of the popular religion of the Sinhalese. Archiv Orientální, 6(1), 5.

Pieris, P. E. (1913). Ceylon: The Portuguese era, (Vol. 1). Colombo Apothecaries.

Pieris, P. E. (1914). Ceylon: The Portuguese era. Being a history of the island for the period 15051658 (Vols. 1-2). Colombo Apothecaries Company.

Pieris, P. E. (1920). Ceylon and the Portuguese, 1505-1658. American Ceylon Mission Press.

Pieris, P. E. (1992). Ceylon, the Portuguese era: Being a history of the island for the period, 1505 1658, Volume 1 (2nd ed.). Tisara Prakasakayo.

Planning Secretariat of the Cabinet (1955). Six year programme of investment, 1954/55 - 1959/60. Ceylon Government Press.

Pridham, C. (1849). An historical, political, and statistical account of Ceylon and its dependencies (Vol, 1). T. and W. Boone.

Raat, A. J. P. (2010). The life of Governor Joan Gideon Loten (1710-1789). A personal history of a Dutch virtuoso. Hilversum.

Rabb, U. N. (2019). The Harita Samhita - A literary review on an ancient Ayurvedic text. Journal of Ayurveda and Integrated Medical Sciences, 4(3), 43-50.

Randall, L. (1977). A comparative economic history of Latin America: 1500-1914 (Vols. 3-4). University Microfilms.

Rasanayagam, C., \& Rasanayagam, M. C. (1984). Ancient Jaffna: Being a research into the history of Jaffna from very early times to the Portuguese period. Asian Educational Services.

Raven-Hart, R. (1964). The Dutch Wars with Kandy, 1764- 1766. Ceylon Historical Manuscripts Commission, Bulletin No. 6. Colombo.

Reimers, E. (Ed.) (1935). Memoir of Joan Gideon Loten, Governor of Ceylon ; delivered to his successor Jan Schreuder on February 28, 1757. Colombo: Ceylon Government Press.

Reports to the Local Government Board on Public Health and Medical Subjects (1918): New Series, Issues 116-124. H.M. Stationery Office.

Rickards, E. (1893). Presidential Address on Infectious Diseases with Especial Reference to Their Treatment by Vaccines. The British Medical Journal, 2(1714), 985-987.

Schrikker, A. (2007). Dutch and British colonial intervention in Sri Lanka, 1780-1815: Expansion \& reforms. Brill.

Schrikker, A., \& Ekama, K. (2017). Through the lens of slavery: Dutch Sri Lanka in the eighteenth century. In Z. Biedermann \& A. Strathern (Eds.), Sri Lanka at the Crossroads of History (pp. 178-193). UCL Press.

Senaveratne, J. M. (1920). Some Sinhalese "superstitions". Ceylon Antiquary and Literary Register, 5(1-4), 155-56.

Sharma, P. V. (1975). The Pseudo-Harita Samhita. Indian Journal of History of Science Calcutta, 10(1), 1-8.

Singh, A. (2010). Fort Cochin in Kerala, 1750-1830: The social condition of a Dutch community in an Indian milieu. Brill. 
Sivaratnam, C. (1964). An outline of the cultural history and principles of Hinduism. Stangard Printers

Sivasundaram, S. (2013). Islanded: Britain, Sri Lanka and the bounds of an Indian Ocean colony. University of Chicago Press.

Small-pox Quarantine Committee. (1852). Report of the Small-pox Quarantine Committee, appointed by order of His Excellency the Governor, with Appendices. W. Skeen, Government printer.

Spinage, C.A. (2012). African ecology-benchmarks and historical perspectives. Springer-Verlag.

Stallybrass, C. O. (1931). The Principles of Epidemiology and the Process of Infection. G. Routledge.

Tennent, E. (1862). Leopards and small-pox in Ceylon. Edinburgh Medical Journal, 8(6), 583-584.

Theal, G. M. (1919). Ethnography and Conditions of South Africa. George Allen \& Unwin.

Thomson, J. (1809). General observations on the cow-pox. A plain statement of facts, in favour of the cowpox, intended for circulation through the middle and lower classes of society. Holden \& Dawson. pp.20

Turner, L.J.B. (1923). Report on the Census of Ceylon 1921. Ceylon Government Press.

United Nations. (1956). Proceedings; papers. Comptes rendus; communications. Actuaciones; monografias. (Vol. 1).

Uragoda, C. G. (1987). History of medicine in Sri Lanka from the earliest times to 1948. Sri Lanka Medical Association. 201-213

Vanderstraaten, J. L. (1886). A brief sketch of the medical history of Ceylon. Journal of the Royal Asiatic Society, Ceylon Branch 9. 306-35.

Van Doornum, G., Van Helvoort, T., \& Sankaran, N. (2020). Dutch virology in the tropics: From colonial to international virology. In Leeuwenhoek's Legatees and Beijerinck's Beneficiaries: A History of Medical Virology in The Netherlands (pp. 203-230). Amsterdam University Press.

Warder, A. K. (2004). Indian Kavya literature: The wheel of time (Vol. 7. Part II). Motilal Banarsidass Publishers.

White, W. (1885) The story of a great delusion in a series of matter-of-fact chapters. E. W. Allen.

Wirz, P. (1954). Exorcism and the art of healing in Ceylon. E. J. Brill.

World Health Organization. (1961). The epidemiological unit in a national health scheme, with particular reference to Ceylon (No. SEA/RC14/4). WHO Regional Office for South-East Asia.

\section{Bibliography}

Andel, Tinde \& Barth, Nadine. (2018). Paul Hermann's Ceylon Herbarium (1672-1679) at Leiden, the Netherlands.

Annual general report (1923). General Report on the Economic, Social and General Conditions of the Island for the year 1922 issued by the Department of Commerce \& Industries. Ceylon.

Anthonisz, S. (1915). Memoir of Thomas van Rhee, Governor and Director of Ceylon, for his Successor, Gerrit de Heere, 1697. H.C. Cottle \& Government Press.

Armstrong, J.C. (1999). "The Ceylon Connection: Convicts and Exiles from Ceylon Sent to the Cape of Good Hope during the Dutch East India Company Period" (paper presented to the interdisciplinary conference "Colonial Places, Convict Spaces: Penal Transportation in Global Context, c. 1600-1940," University of Leicester, 9-10 December 1999. 
Baas, P. (2017). The golden age of Dutch colonial botany and its impact on garden and herbarium collections. Tropical Plant Collections: Legacies from the Past, 53-62.

Bartholomeusz, F. (1943). The story of Hendala. Journal of the Dutch Burgher Union. Dutch Burgher Union of Ceylon.

Bates, C. (Ed.). (2003). Community, Empire and Migration: South Asians in Diaspora. Orient Longman.

Breckenridge, S.N. (2001). The Hills of Paradise: British Enterprise and the Story of Plantation Growth in Sri Lanka. Pannipitiya: Stamford Lake.

Bruijn, M. de \& R. Raben (2004). The world of Jan Brandes 1743-1808. Drawings of a Dutch traveller in Batavia, Ceylon and southern Africa. Zwolle: Waanders.

Burrows, E.H. (1958). History of Medicine in South Africa. Cape Town.

Ceylon Health Department (1965). Saukya Seva Adhyaksage Palana Vartava. Colombo.

Ceylon Sessional Papers (1916). Ceylon Government Press.

Christie, T. (1812). Letters on Vaccination in Ceylon. The Edinburgh Medical and Surgical Journal. David Willison.

CO 54 / 902 / 16 , 1930 Report of the Committee Appointed to Consider the Medical Wants Ordinance and the Diseases ( Labourers ) Ordinance, Nos . 9 and $10,1912$.

Courtenay, P., \& Francis, M. G. (1999). History of Ceylon: An Abridged Translation of Professor Peter Courtenay's Work. Asian Educational Services.

Cumpston, J.H.L. \& McCallum, F. (1925). The History of Small-Pox in Australia; 1909-1923; Service Publication Number 29. Melbourne: H.J. Green. Government printer.

Dassanayake, M.D. and Fosberg F.R. (1996). (Eds.). A Revised Handbook of the Flora of Ceylon. A.A. Balkema. .

Davidson, A. (1892). Geographical Pathology: An Inquiry into the Geographical Distribution of Infective and Climatic Diseases. Volume I: Europe, Northern and Western Asia, India Ceylon, Burma. Y.J. Pentland.

De Lanarolle V. D. (1960). (Ed.). Purana Sinhala Tovil Kavi. MD Gunasena.

De Silva, R.K. and Beumer, W.G.M. (1988). Illustrations and Views of Dutch Ceylon, 1602-1796: A Comprehensive Work of Pictorial Reference with Selected Eyewitness Accounts. E.J. Brill.

Elphick, R., \& Giliomee, H. (Eds.). (2014). The Shaping of South African Society, 1652-1840. Wesleyan University Press.

Falisevac, J., Arumanayagam, P., Sivaganaratnam, K., Slvaganam, C., \& Padley, R. (1960). A Smallpox Outbreak at Leyden Island, Ceylon, 1958. Ceylon Medical Journal, 5(4), 183-94.

Fellowes, R. (1817). The History of Ceylon: From the Earliest Period to the Year MDCCCXV; with Characteristic Details of the Religion, Laws, \& Manners of the People and a Collection of Their Moral maxims and ancient proverbs. Joseph Mawman.

Forbes. J., Tweedie. A. and Conolly. J. (Eds.). (1830). The Cyclopedia of Practical Medicine vol. 1. Sherwood, Gilbert, and Piper, and Baldwin and Cradock.

Foreign Reports. (1914). Public Health Reports (1896-1970), 29 (32), 2083-2089.

Foreign Reports. (1915). Public Health Reports (1896-1970), 30(47), 3429-3438.

Foreign Reports. (1916). Public Health Reports (1896-1970), 31(32), 2165-2171.

Foreign Reports. (1919). Public Health Reports (1896-1970), 34(48), 2742-2759. 
Foreign Reports. (1943). Public Health Reports (1896-1970), 58(28), 1073-1075.

Foreign Reports. (1948). Public Health Reports (1896-1970), 63(17), 554-556.

Gear, H.S. (1956). Disease control and international travel: a review of the international sanitary regulations. World Health Organization.

Geyser, O. (1982). The history of the old Supreme Court building. Johannesburg: Africana Press.

Goonetillake, R. (2017, January 20). White South Africans at Diyatalawa in Sri Lanka. The Island.

Hrozny, B. (1934). Archiv Orientální: Journal of the Czechoslovak Oriental Institute, Prague, Volume 06.

Hooft, H. G. A., \& Hooft, H. (1999). Patriot and Patrician: To Holland and Ceylon in the Steps of Henrik Hooft and Pieter Ondaatje, Champions of Dutch Democracy. Science History Publications.

House of Commons Sessional Papers (1902). Sessional Papers, Volume 66. House of Commons.

Institute of Economic Growth (1971). Studies in Asian Social Development, Issue 1.

Interim Commission of the World Health Organization (1965). Releve Epidemiologique Hebdomadaire, 40.

Jones, M. (2004). Health policy in Britain's model colony: Ceylon, 1900-1948 (Vol. 10). Orient Blackswan.

Journal of the Ceylon Branch of the Royal Asiatic Society, Vol. 8-9 (1962). Colombo: Colombo Apothecaries Company.

King, J., \& Hamilton, J. (1891). Foreign. Abstract of Sanitary Reports, 6(11), 120-124.

Kotar, S. L., \& Gessler, J. E. (2013). Smallpox: a history. McFarland.

Knox, R. (1681). An Historical Relation of the Island Ceylon.

Lekamwasam, S. (2006). Medical History of Galle. Journal of the Galle Medical Association, 22(1), 35- 36.

Liesching, L.F. (1861). A Brief Account of Ceylon. Jaffna: Ripley and Strong.

Marshall, J. (1911). Mediaeval Sinhalese Art. By Ananda K. CoomaraswamyD.Sc., Fellow of University College, London. Printed under the care of the author at the Essex House Press, Broad Campden, Gloucestershire, 1908. Journal of the Royal Asiatic Society, 43(3), 839-843. doi:10.1017/S0035869X00042088

Mills, L.A. (2012). Ceylon under British Rule, 1795-1932. London: Frank Cass \& Co. Ltd.

Moldrich, D. (1989). Bitter berry bondage: the nineteenth century coffee workers of Sri Lanka. Coordinating Secretariat for Plantation Areas.

Nevill, H. (1887). The Gadi or Rodi race in Ceylon. The Taprobanian, 2(3), 81-96.

Nyanatiloka Thera, Hecker, H., \& Bhikkhu Nyanatusita. (Eds.). (2008). The Life of Nyanatiloka Thera: The Biography of a Western Buddhist Pioneer. Buddhist Publication Society.

Obeyesekere, D. (1999). Outlines of Ceylon History. New Delhi: Asian Education Services Publications.

Perera, A. A. (1917). Sinhalese Folklore Notes: Ceylon. British India Press, Mazgoan.

Percival, R. (1805). An Account of the Island of Ceylon: Containing Its History, Geography, Natural History, with the Manners and Customs of Its Various Inhabitants. C. and R. Baldwin.

Pieris, P.E. (1918). Ceylon and the Hollanders, 1658-1796. Tellippalai: American Ceylon Mission. Quarterly Bulletin: Kwartaalblad, Volumes 7-8 (1952). South African Public Library. 
Ranasinha, A.G. (1950). Department of Census and statistics; Census of Ceylon 1946. Ceylon Government Press.

Report of the Principal Civil Medical Officer and Inspector General of Hospitals for (1918). Ceylon Government Printer.

Ribeiro, J. (1847). History of Ceylon: Presented by Captain John Ribeyro to the King of Portugal. Ceylon Government Press.

Shell, R. (1986). Slavery at the Cape of Good Hope 1680 - 1731 (PhD thesis). Yale University.

Simmons, S.J., Whayne, T.F., \& Anderson, G.W. (1944). Global Epidemiology, a Geography of Disease and Sanitation: pt. 1. India and the Far East. pt. 2. The Pacific area. Lippincott.

Sivasubramaniam, K. (2009). Fisheries in Sri Lanka: anthropological and biological aspects, Volume 1. Colombo: Kumaran Book House.

Shisana, O. (2011) The South African healthcare system: a goal of quality healthcare for all. Medical Solutions. September: 91-95.

SLNA, 1/193, 22 June 1786, minute political council Ceylon.

Sri Lanka Department of Health Services (1968). Administration Report for the year 1967. Ceylon Government Press.

Suckling, H. J. (1876). Ceylon: A General Description of the Island, Historical, Physical, Statistical (Vol. I). Bradbury Agnew \& Co.

Sydney. (1893). The British Medical Journal, 2(1711), 865-865.

Tagliocozzo, E. (2013). The Longest Journey: Southeast Asians and the Pilgrimage to Mecca. Oxford University Press.

Theal, G. M. (1887). History of the Boers in South Africa. Swan Sonnenschein.

Tillakaratne, M.P. (1967). Customs and Institutions connected with the Domestic life of the Sinhalese in the Kandyan Period. University of London.

"To the Editor of the Times from F.R.G." Times of London, August 17, 1880, p. 8.

University of Peradeniya (1995). History of Sri Lanka. Peradeniya.

Public Health Service (1917). Public Health Reports; Volume 31- Part 2. Numbers 27-52, JulyDecember, 1916. Government Printing Press.

United States Public Health Service (1948). Public Health Reports, 63(I) January-June 1948. Government Printing Press

Vital Statistics. (1960). The British Medical Journal, 2(5206), 1168-1169.

Ward, K. (2009). Networks of Empire: Forced Migration in the Dutch East India Company. Cambridge University Press.

Waterhouse, J. (1875). Report on the Observation of the Total Solar Eclipse of 6th April 1875 at Cumorta, Nicobar Islands. Calcutta Press.

Webb, J.L.A. (2002). Tropical Pioneers: Human Agency and Ecological Change in the Highlands of Sri Lanka, 1800-1900. Ohio University Press.

Weerasooriya, W.S. (1973). The Nattukottai Chettiar Merchant Bankers in Ceylon. Dehiwela: Tisara Press.

Westra,P. \& Armstrong J.C. (2006). Slave Trade with Madagascar: The journals of the Cape slaver Leijdsman, 1715. Africana Publishers. 